\title{
A Systematic Review on Prevention and Treatment of Nipple Pain and Fissure: Are They Curable?
}

\author{
Azin Niazi ${ }^{1+}$, Vafa Baradaran Rahimi ${ }^{2+}$, Sina Soheili-Far ${ }^{5}$, Nafiseh Askari ${ }^{4}$, Pouria \\ Rahmanian-Devin ${ }^{5}$, Zahra Sanei-Far ${ }^{2}$, Amirhossein Sahebkar ${ }^{7}$, Hassan Rakhshan- \\ deh $^{6}$, Vahid Reza Askari $2,6,3 *$
}

${ }^{1}$ Graduate student of Midwifery, School of Nursing and Midwifery, Mashhad University of Medical Sciences, Mashhad, Iran

${ }^{2}$ Student Research Committee, Department of Pharmacology, Faculty of Medicine, Mashhad University of Medical Sciences, Mashhad, Iran

${ }^{3}$ Neurogenic Inflammation Research Center, Mashhad University of Medical Sciences, Mashhad, Iran

${ }^{4}$ Student Research Committee, Sabzevar University of Medical Sciences, Sabzevar, Iran

${ }^{5}$ Student Research Committee, School of Pharmacy, Mashhad University of Medical Sciences, Mashhad, Iran

${ }^{6}$ Pharmacological Research Center of Medicinal Plants, Mashhad University of Medical Sciences, Mashhad, Iran

${ }^{7}$ Biotechnology Research Center, Pharmaceutical Technology Institute, Mashhad University of Medical Sciences, Mashhad, Iran

\section{Key Words}

pain, fissure, clinical trial, systematic review, nipple, prevention

\begin{abstract}
Averagely $80 \%$ to $90 \%$ of breastfeeding women experience the nipple pain and fissures. The important factor for successful breastfeeding is to treat this problem. This study has done as a review with the aim of analysis of the clinical trials in the field of the prevention and treatment of the nipple fissures and pain due to the importance of breastfeeding. For this purpose, the key words of sore, nipples, fissure, trauma, wound, prevention, treatment, therapeutics, therapy, clinical trial, breastfeeding and their Persian synonyms and all of their possible combinations were searched in the national databases: SID and Iran Medex and Magiran, and in the international databases: PubMed, Scopus, Medline, Science direct by May 2017. The Jadad criterion was used to assess the quality of the articles and the articles with a score of 3 or more were included in this study. Finally, 48 clinical trials were reviewed that 17 of them (sample size 1801) scored 3 or more based on the Jadad criterion. Seven ar-
\end{abstract}

Received: Feb 08, 2108 Reviewed: Apr 16, 2018 Accepted: Aug 02,2018

(C) This is an Open-Access article distributed under the terms of the Creative Common Attribution Non-Commercial License (http://creativecommons.org/licenses/by-nc/4.0/) which permits unrestricted noncommercial use, distribution, and reproduction in any medium, provided the original work is properly cited.

(2) This paper meets the requirements of KS X ISO 9706, ISO 9706-1994 and ANSI/NISO Z39.48-1992 (Permanence of Paper) ticles were also in the non- drug treatment group (sample size 491) and 2 articles in the drug treatment group (sample size 337) and 8 articles in the herbal treatment group (sample size 973). The results show that menthol and warm water compress as well as teaching the correct breastfeeding methods are effective treatments to prevent and treat the nipple pain and fissures. Moreover, applying the herbal medicine for prevention and treatment of the issues raised from breastfeeding may have beneficial such as Aloe vera, Portulaca olearacea. However, more studies with a great methodology are necessary to obtain more accurate evidence.

\section{Introduction}

Breast milk is a good food for babies which contains almost all the needed nutrients for the their growth and safety [1]. The World Health Organization (WHO) and United Nations Children's Fund (UNICEF) have recommended just breastfeeding in the first 4 to 6 months of infancy and its continuation until 2 years along with supplementary feeding [2]. According to the recent estimation of WHO, although $98 \%$ of the world women are physiologically able to breastfeed [3], but only $35 \%$ of the world babies are breastfed between their birth and fifth months [4]. The nipple wound and sore are

"Corresponding Author

Vahid Reza Askari. Student Research Committee, Department of Pharmacology, Faculty of Medicine, Neurogenic Inflammation Research Center, Mashhad University of Medical Sciences, Mashhad, Iran.

Tel: +98-513-8002-262 Fax: +98-511-8828-564

E-mal: askariv941@mums.ac.ir, vahidrezaaskary@yahoo.com.

+ The authors had equal contribution as first author.

C) 2018 Korean Pharmacopuncture Institute

http://www.journal.ac 
the common reasons reported by women to early stop of breastfeeding, which can cause an unpleasant experience in breastfeeding and its stop [5]. Most of mothers affected to mastitis, breast fissure and milk stop in the breast, continue breastfeeding up to 3 months after childbirth [6].

The breast fissure is a macroscopic cutaneous lesion in the tip and areola around the breast, which is seen in the form of a cleft, loss of skin, wound or clinical evidence of erythema, edema and blister [7]. The nipple pain and fissure are experienced by $80 \%$ to $90 \%$ of the breastfeeding women [8]. Incorrect breastfeeding and inappropriate nipple sucking are the most common causes of the breast fissure. Other possible causes of the nipple trauma and pain are nipple infection with Staphylococcus aureus and Candida albicans, strong or weak infant sucking, short frenulum, nipple wash with soap and the use of pacifier or baby bottle $[5,9]$.

Untreated breast fissures may lead to problems such as severe pain, the nipple bleeding and inadequate milk secretion, mastitis and breast abscess [9]. The pain causing breast fissure reduces the production and secretion of breast milk and finally creating stress in the mother and stopping breastfeeding due to its inhibitory effects on oxytocin production [10]. Swallowing the nipple fissure blood can lead to blood vomiting in the infant [6]. The quick and effective treatment of such problem is an important factor in the success of breastfeeding and prevention of mastitis and breast abscess [10]. Topical ointments, solutions or spray, breastfeeding time limitation, exposure of the nipple to the air and light, teaching the correct breastfeeding methods, rubbing milk on the nipple, hydrogel, hot water compress, mint extract, tea bag, collagenase ointment, dexpanthenol and lanolin are the methods used for the nipple pain and fissure prevention and treatment [9].

Herbal medicine has a close relation with the history of human life and their use has always been among the therapeutic methods [11-15]. There is no proven treatment for the breast fissure [16]. However, the effect of any of these treatments had not been conclusively proven [8]. Given that, the review studies are due to their exact structure, a standard source to make evidence in health care [17] and lack of available clinical information and evidence in the field of the nipple fissure and pain prevention and treatment, then we have done the current study with the pur-
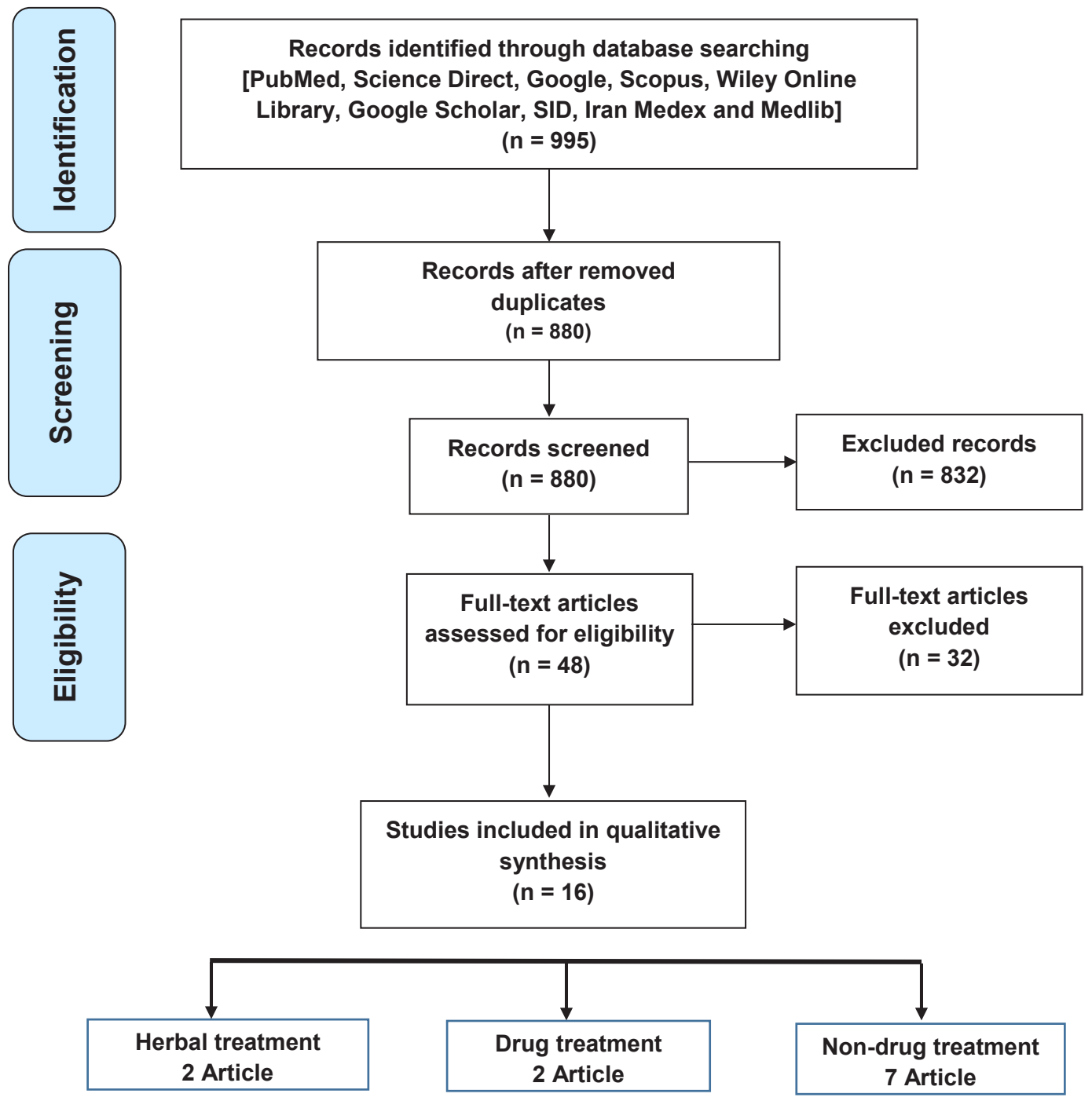

Figure 1 Flow diagram for systematic review 
pose of summarizing the conducted clinical trials in this area.

\section{Methods}

The current study is a systematic review with the purpose of examining the pharmacological and non-pharmacological intervention to prevent and treatment of the nipple fissure and pain. For this reason, the keywords of sore, nipples, fissure, trauma, wound, prevention, treatment, therapeutics, therapy, clinical trial, breastfeeding and their Persian synonyms and all their possible combinations, were searched in the national databases: SID and Iran medex and MagIran and in the international databases: PubMed, Scopus, Medline, Science Direct, and Cochrane Library. There was no time limitation for the search and the published articles until May 2017 were searched. A list of the related articles' references was manually examined to find other possible sources in order to maximize comprehensiveness of search. All of the published articles in Persian or English which have reviewed the nipple fissure and pain prevention and treatment methods were the main criteria to include these articles into this structured review. Non-related, repeated or the review articles which were letters to editor were not included. We have used the information in the abstract if the full text of the article was not available and if there was not enough information in the abstract, then the article was excluded of this study. Figure 1 also shows the process of studies, including and excluding in the current study. The Jadad criterion was used to qualitatively evaluate the articles. This criterion will assess the articles based on how their participants are randomized, randomization methods, blinding and its method which the minimum and maximum score of it are 1 and 5, respectively [18]. On the basis of this criterion those articles with a score of 3 or more were included in the study.

\section{Results and Findings}

Forty eight clinical trials were finally reviewed that 17 of them (sample size 1801) have scored 3 or more based on Jadad criterion. 7 articles were included in non-drug treatment group (sample size 491), 2 articles were in the drug treatment group (sample size 337) and there were 8 articles in the herbal treatment group (sample size 973). Most examined herbal medicines have constituents including saponins, flavonoids and terpenoid that had good effects on the nipple fissure and pain treatment due to their analgesic and healing properties $\mathrm{Z}$.

\subsection{Hydrogel /Lanolin and Midwifery Standard Care}

It is made of the hydrophilic polymer which helps to grow new tissue by creating a humid environment in the wound site. Hydrogel will reduce the pain by creating a cold sur- face on the wound. Hydrogel dressing can be easily and removed from the wound site without feel-ing sore [19].

Brent et al. (1998) has compared the effectiveness of hydrogel dressing in the experimental group with lanolin and breast protector in the control group. Mothers in both groups were taught the correct breastfeeding methods. Mothers in the experimental group used hydrogel dressing immediately after massaging the nipple with their milk and before milk drying, but mothers in the control group were asked to use lanolin and breast protection after milk drying. They have examined the pain severity and wound size in the most 3 times in 10 days or until the symptoms were removed. Standard 4-degree questionnaires have been used to measure the wound healing. Redness, edema, ecchymosis and desquamation, as well as secretions cri-teria examined using this questionnaire. The scaling with 11 degrees was used to measure the pain in which $0=$ not feeling the pain and $11=$ severe pain. The fissure severity mean was 4.5 and 5.78 before treatment in the control and experimental group, respectively, and at the fol-lowing up time of treatment it was respectively 2.33 and 4.87 in the control and experimental group. According to the results, the recovery rate was significantly more in the lanolin and the breast protector group than the hydrogel group. Mothers in the lanolin and breast protector have experienced significantly lower pain during breastfeeding than the hydrogel group $(\mathrm{p}<0.05)[20]$.

Centuori et al. (1999) have studied the effect of midwifery standard care on subjects that received no treatment and they just received the usual care of midwifery, including using the ointment or the spray in the control group (ointment ingredients including albumin, glycerin, casein, paraffin oil, lanolin, gel, petroleum, zinc oxide, sodium hydride and potassium, and spray components including cholesterol $0.15 \mathrm{~g}$ and neomycin sulfate $0.15 \mathrm{~g}$ in 30 $\mathrm{ml}$ ). The ex-amination was done at the time of discharge, 2 weeks and 3 months after the intervention and through observing and measuring the fissure site. The results suggested that the nipple fissure and breastfeeding duration are not affected by ointment, but teaching the correct breastfeed-ing methods and supporting the mother are more effective [21].

The lanolin will prevent the wounds by creating a humid skin and heal the wounds by in-creasing the epithelial regrowth rate. Ester is the active ingredient of lanolin. Esters have the wound healing property in a humid environment as well as the anti-inflammatory, anti-bacterial, skin protector and healing barrier. When the breast tissue is injured, then the chemi-cals like Histamine and bradykinin are released at the injury site and cause pain. The lanolin will increase the healing by maintaining the injured tissue moisture and reduces the amount and duration of the exposure to these chemicals and thus relieves the pain [22]. In Jackson et al (2016) study the research units were randomly placed in one of these 2 groups: the lanolin or the standard care (breastfeeding advice, mother breastfeeding method assessment, hot or cold compress usage, Ibuprofen or acetaminophen and nipple drying by air exposure). Both groups were taught the correct breastfeeding method. Mothers in the experi-mental group were asked to use a little amount of the lanolin on their nipple and repeat this 
Table 1 Conducted Trials in the field of nipple fissure prevention and pain

\begin{tabular}{|c|c|c|c|c|c|c|c|}
\hline $\begin{array}{l}\text { Ja- } \\
\text { dad }\end{array}$ & $\begin{array}{l}\text { Com- } \\
\text { plica- } \\
\text { tions }\end{array}$ & Control group & $\begin{array}{l}\text { Experimental } \\
\text { group }\end{array}$ & $\begin{array}{l}\text { Research sam- } \\
\text { ple }\end{array}$ & Method & Results & Ref \\
\hline 4 & $\begin{array}{l}\text { Infec- } \\
\text { tion } \\
\text { in the } \\
\text { hy- } \\
\text { drogel } \\
\text { group }\end{array}$ & $\begin{array}{l}\text { Breast milk, } \\
\text { lanolin and } \\
\text { breast protector } \\
21 \text { people }\end{array}$ & $\begin{array}{c}\text { Breast milk and } \\
\text { hydrogel } 21 \text { people }\end{array}$ & $\begin{array}{l}42 \text { breastfeed- } \\
\text { ing women } \\
\text { suffered from } \\
\text { nipple fissure }\end{array}$ & Clinical trial & $\begin{array}{l}\text { Mothers using the } \\
\text { lanolin and breast } \\
\text { protector have expe- } \\
\text { rienced significantly } \\
\text { lower pain during } \\
\text { breastfeeding than } \\
\text { the hydrogel group }\end{array}$ & [20] \\
\hline 5 & & $\begin{array}{c}\text { Placebo Pho- } \\
\text { totherapy } 8 \\
\text { people }\end{array}$ & $\begin{array}{c}\text { Phototherapy } 8 \\
\text { people }\end{array}$ & $\begin{array}{l}16 \text { breastfeed- } \\
\text { ing women } \\
\text { suffered from } \\
\text { nipple fissure }\end{array}$ & $\begin{array}{l}\text { Double-blind } \\
2 \text { groups } \\
\text { randomized } \\
\text { clinical trials }\end{array}$ & $\begin{array}{l}\text { Nipple fissure and } \\
\text { breastfeeding dura- } \\
\text { tion are not affected } \\
\text { by ointment, but } \\
\text { teaching the correct } \\
\text { breastfeeding meth- } \\
\text { ods and supporting } \\
\text { the mother are more } \\
\text { effective }\end{array}$ & [21] \\
\hline 5 & & $\begin{array}{c}\text { Laser treatment } \\
\text { placebo } \\
29 \text { people }\end{array}$ & $\begin{array}{c}\text { laser therapy } 30 \\
\text { people }\end{array}$ & $\begin{array}{l}59 \text { breastfeed- } \\
\text { ing women } \\
\text { suffered from } \\
\text { nipple fissure }\end{array}$ & $\begin{array}{l}\text { Double-blind } \\
2 \text { groups } \\
\text { randomized } \\
\text { clinical trials }\end{array}$ & $\begin{array}{c}\text { Pain is greatly } \\
\text { reduced }\end{array}$ & [28] \\
\hline 3 & & $\begin{array}{c}\text { Standard care, } \\
\text { using milked } \\
\text { breast milk } 20 \\
\text { people }\end{array}$ & $\begin{array}{l}\text { Silver cap } 20 \\
\text { people }\end{array}$ & $\begin{array}{l}40 \text { women } \\
\text { suffered from } \\
\text { fissure }\end{array}$ & Clinical trial & $\begin{array}{c}\text { Reduced Pain } \\
\text { Observed fissure } \\
\text { healing }\end{array}$ & [30] \\
\hline 3 & & Non-treatment & Polyethylene & $\begin{array}{l}50 \text { women } \\
\text { suffered from } \\
\text { fissure }\end{array}$ & Clinical trial & $\begin{array}{c}\text { Observed no effects } \\
\text { on Pain } \\
\text { Observed fissure } \\
\text { healing }\end{array}$ & [31] \\
\hline 5 & & $\begin{array}{c}\text { Each sample } \\
\text { was considered } \\
\text { its own control }\end{array}$ & $\begin{array}{c}\text { Tea bag and hot } \\
\text { water compress (21 } \\
\text { people). } \\
\text { Hot water com- } \\
\text { press on one breast } \\
\text { and non-treatment } \\
\text { of the other breast } \\
\text { (22 people). } \\
\text { Tea bag on } \\
\text { one breast and } \\
\text { non-treatment the } \\
\text { other breast ( } 22 \\
\text { people) }\end{array}$ & $\begin{array}{l}65 \text { women } \\
\text { suffered from } \\
\text { fissure }\end{array}$ & $\begin{array}{l}\text { Blinded for- } \\
\text { ward looking } \\
\text { clinical trial }\end{array}$ & $\begin{array}{c}\text { Effective in the pain } \\
\text { relief }\end{array}$ & [33] \\
\hline
\end{tabular}




\begin{tabular}{|c|c|c|c|c|c|c|c|}
\hline $\begin{array}{l}\text { Ja- } \\
\text { dad }\end{array}$ & $\begin{array}{l}\text { Compli- } \\
\text { cations }\end{array}$ & Control group & $\begin{array}{l}\text { Experimental } \\
\text { group }\end{array}$ & Research sample & Method & Results & Ref \\
\hline
\end{tabular}

\begin{tabular}{|c|c|c|c|c|c|c|}
\hline 4 & - & $\begin{array}{l}\text { Midwife- } \\
\text { ry routine } \\
\text { treatment (96 } \\
\text { people) }\end{array}$ & $\begin{array}{c}\text { Avoid any } \\
\text { treatment (123 } \\
\text { people) }\end{array}$ & $\begin{array}{l}219 \text { breastfeeding } \\
\text { women }\end{array}$ & Clinical trial & $\begin{array}{c}\text { Teaching the correct } \\
\text { breastfeeding meth- } \\
\text { ods and supporting } \\
\text { the mother are more } \\
\text { effective }\end{array}$ \\
\hline
\end{tabular}

\begin{tabular}{|c|c|c|c|c|c|c|c|}
\hline 5 & - & $\begin{array}{l}\text { Routine care } \\
\text { (93 people) }\end{array}$ & $\begin{array}{l}\text { Lanolin (93 } \\
\text { people) }\end{array}$ & $\begin{array}{l}186 \text { breastfeeding } \\
\text { women suffered } \\
\text { from nipple } \\
\text { fissure }\end{array}$ & $\begin{array}{l}\text { Blinded } \\
\text { clinical trial }\end{array}$ & $\begin{array}{l}\text { Increase the healing } \\
\text { No effect on the } \\
\text { nipple pain }\end{array}$ & [10] \\
\hline 5 & $\begin{array}{l}\text { Irrita- } \\
\text { tion and } \\
\text { nipple } \\
\text { itching } \\
\text { in both } \\
\text { groups }\end{array}$ & $\begin{array}{l}\text { Lanolin } 76 \\
\text { people }\end{array}$ & $\begin{array}{l}\text { All-Purpose Nip- } \\
\text { ple Ointment } \\
75 \text { people }\end{array}$ & $\begin{array}{l}151 \text { breastfeeding } \\
\text { women suffered } \\
\text { from nipple } \\
\text { fissure }\end{array}$ & $\begin{array}{l}\text { Double } \\
\text { blind clini- } \\
\text { cal trial }\end{array}$ & $\begin{array}{l}\text { Not superior effects } \\
\text { to lanolin }\end{array}$ & [23] \\
\hline 3 & - & $\begin{array}{l}\text { Milked breast } \\
\text { milk } 77 \text { people }\end{array}$ & $\begin{array}{c}\text { Guaiazulene } \\
\text { ointment }(0.05) \\
76 \text { people }\end{array}$ & $\begin{array}{l}153 \text { breastfeeding } \\
\text { women with no } \\
\text { nipple fissure and } \\
\text { pain }\end{array}$ & $\begin{array}{l}\text { Double } \\
\text { blind clini- } \\
\text { cal trial }\end{array}$ & $\begin{array}{l}\text { Effectively prevent } \\
\text { the nipple fissure } \\
\text { incidence }\end{array}$ & [48] \\
\hline 3 & - & $\begin{array}{l}\text { Milked breast } \\
\text { milk } 41 \text { people }\end{array}$ & $\begin{array}{l}\text { Calendite oint- } \\
\text { ment } 41 \text { people }\end{array}$ & $\begin{array}{l}82 \text { breastfeeding } \\
\text { women suffered } \\
\text { from nipple } \\
\text { fissure }\end{array}$ & $\begin{array}{l}\text { Blind clini- } \\
\text { cal trial }\end{array}$ & $\begin{array}{l}\text { More effective than } \\
\text { the breast milk }\end{array}$ & [37] \\
\hline 4 & - & $\begin{array}{l}\text { Milked breast } \\
\text { milk } 50 \text { people }\end{array}$ & $\begin{array}{l}\text { Jujube lotion } 50 \\
\text { people }\end{array}$ & $\begin{array}{l}100 \text { breastfeeding } \\
\text { women suffered } \\
\text { from nipple } \\
\text { fissure }\end{array}$ & $\begin{array}{l}\text { Double } \\
\text { blind clini- } \\
\text { cal trial }\end{array}$ & $\begin{array}{l}\text { More effective in } \\
\text { the nipple pain relief } \\
\text { than the breast milk }\end{array}$ & [40] \\
\hline 4 & - & $\begin{array}{l}\text { Lanolin oint- } \\
\text { ment }\end{array}$ & A. vera gel & $\begin{array}{l}100 \text { breastfeeding } \\
\text { women suffered } \\
\text { from nipple } \\
\text { fissure }\end{array}$ & $\begin{array}{c}\text { Blinded } \\
\text { clinical trial }\end{array}$ & $\begin{array}{l}\text { Reduced Pain } \\
\text { Observed fissure } \\
\text { healing }\end{array}$ & [6] \\
\hline 3 & & $\begin{array}{l}\text { Milked breast } \\
\text { milk } 55 \text { people }\end{array}$ & $\begin{array}{l}\text { Menthol essence } \\
55 \text { people }\end{array}$ & $\begin{array}{l}110 \text { breastfeeding } \\
\text { women suffered } \\
\text { from nipple } \\
\text { fissure }\end{array}$ & Clinical trial & $\begin{array}{l}\text { Menthol essence } \\
\text { relieved the pain and } \\
\text { healed the nipple } \\
\text { fissure }\end{array}$ & [45] \\
\hline
\end{tabular}




\begin{tabular}{|c|c|c|c|c|c|c|c|}
\hline 5 & - & - & $\begin{array}{l}\text { Menthol } 42 \text { people } \\
\text { Dexpanthenol } \\
42 \text { people } \\
\text { Lanolin } 42 \text { people }\end{array}$ & $\begin{array}{l}126 \text { breastfeed- } \\
\text { ing women } \\
\text { suffered from } \\
\text { nipple fissure }\end{array}$ & $\begin{array}{c}\text { Double blind } \\
\text { clinical trial }\end{array}$ & $\begin{array}{c}\text { Increase the healing } \\
\text { Relieves the pain }\end{array}$ & [22] \\
\hline 4 & - & $\begin{array}{c}\text { Placebo } \\
72 \text { people }\end{array}$ & $\begin{array}{l}\text { Mint gel } 72 \text { people } \\
\text { Lanolin } 72 \text { people }\end{array}$ & $\begin{array}{l}216 \text { breastfeed- } \\
\text { ing women }\end{array}$ & $\begin{array}{l}\text { Double blind } \\
\text { clinical trial }\end{array}$ & $\begin{array}{l}\text { More effective in } \\
\text { the nipple fissure } \\
\text { prevention than each } \\
\text { one of lanolin and } \\
\text { placebo }\end{array}$ & {$[46]$} \\
\hline & $\begin{array}{l}\text { Infection, } \\
\text { irritation } \\
\text { in the } \\
\text { lanolin } \\
\text { group }\end{array}$ & $\begin{array}{l}\text { Lanolin } \\
43 \text { people }\end{array}$ & $\begin{array}{c}\text { P. oleracea ointment } \\
43 \text { people }\end{array}$ & 5 & $\begin{array}{l}\text { Double blind } \\
\text { clinical trial }\end{array}$ & $\begin{array}{c}\text { Significantly re- } \\
\text { duced pain severity }\end{array}$ & [53] \\
\hline
\end{tabular}

until there is no pain or until the end of the duration. The control group received the routine care. The NRS tool was used to measure the pain severity and in order to measure the pain quality we have used the McGill questionnaire. A research assistant who was not aware of the treatment type made a phone call to the mothers in the 4th and 7th days after the intervention and asked them about the nipple pain. The research assistant collected the data in the 4th and 7 th days after the intervention and the 4th and 12th weeks after delivery. The results indicated that lanolin had no effect on the nipple pain [10].

Dennis et al (2012) have shown that All-Purpose Nipple Ointment (APNO) ointment con-taining an antibacterial agent (15 g of $2 \% \mathrm{w} / \mathrm{w}$ Mupirocin), an antifungal agent ( $15 \mathrm{~g}$ of $2 \% \mathrm{w} / \mathrm{w}$ miconazole ) and a hydrocortisone (15 $\mathrm{g}$ of $0.1 \%$ $\mathrm{w} / \mathrm{w}$ omeprazole)) and the lanolin were prescribed for the intervention and the control group, respectively. The pharmacists have as-signed the APNO and lanolin in similar tubes. The research units were asked to dry the breast after each breastfeeding and use the drug and rub it around the areola and not to clean it till the next breastfeeding while not using any other drugs during the research for the nipple pain relief. Both groups were taught the correct breastfeeding methods. The McGill Pain Ques-tionnaire (including 15 items, emotional and mental aspects of pain) and the nipple assessment questionnaire were used in this study. The pain severity and the nipple soreness were checked through a phone call by the researcher 1 and 12 weeks after the intervention. There was no significant statistical difference between the two groups in the mean score of the pain and healing duration of the first week after the intervention. $(\mathrm{p}=0.97)$. The results showed that the common ointment to heal the nipple fissure was not superior to lanolin [23].

\subsection{Phototherapy (LED)}

Phototherapy, in the range of 630 to $1000 \mathrm{~nm}$, is an effective tool in regeneration of tissue that will increase the wound healing rate through increasing the proliferation of fibroblasts, collagen synthesis and its progenitor as well as stimulate the angiogenesis and production of growth factor $[24,25]$.

Chaves et al (2012) has shown the effects of phototherapy on the nipple fissure healing rate on 16 breastfeeding women suffered from the fissure. The women were randomly divided into 2 groups. Both groups were taught the correct breastfeeding methods and the nipple care. Phototherapy and placebo phototherapy were prescribed for the intervention and control group twice a week in 8 sessions, respectively. The nipple was photographed before intervention and during 8 sessions of treatment. The images obtained by Quantikov software were examined. The pain severity was measured in all treatment sessions before and after phototherapy using the PI-NRS 11-degrees tool. The PGIC standard tool was used to determine the pain status and the participants recorded their pain status at the end of each session. The results suggested that phototherapy reduces the pain severity and the nipple wound size so that the nipple fissure of research units in the experimental group was fully healed after 4 sessions of treatment while same healing was achieved in the control group at the eighth session. Although, the pain severity was reduced in both groups, but this reduction was only significant in the experimental group. $(p=0.001)$. The participants in the phototherapy group reported their status highly healed at the end of the treatment [25].

\subsection{Low-level laser therapy (LLLT)}

These lasers are also named as bio-stimulating or low intensity lasers. Wound healing, stimulation of cellular processes, pain reduction, local blood flow acceleration and attenuation of inflammation has been mentioned as advantages of this therapeutic approach [26]. The followings could be listed as the biological effects of laser therapy:

a) Increasing the blood flow rate through vascular dilatation 
b) Changing the hydrostatic pressure in capillaries

c) Stimulating the immune processes,

d) Stimulating the fibroblasts growing,

e) Increasing the collagen synthesis,

f) Generating new vessels and capillaries and

g) Decreasing the prostaglandin levels which lead to increase wound healing rate and the pain and inflammation reduction [27].

Coca et al (2016) has carried out an investigation entitling the effects of low level laser on the nipple pain severity in breastfeeding women in Sao Paula. The experimental group has been treated using low level laser, in this way that a 40-milliwatt laser beam was radiated into three consecutive points (center, left and right) on the nipple wound, but the red light, lacking health benefits and strength, was used for the control group. In this study, the patients and the two applier nurses were blinded and unaware of the treatment types. The treatment was done in three sessions $(0,24$ and 48 hours after fissure detection) for both groups. VAS scale, including a non-grading $10 \mathrm{~cm}$ line, was used to measure the mothers' nipple pain level during breastfeeding. Mothers marked their pain level before and after each session. The pain severity mean before the intervention in both groups was $6.4 \mathrm{~cm}$ at the first session, while this amount had a statistically significant decrease of $1.3 \mathrm{~cm}$ after laser radiation in the experimental group $(p=0.05)$. The mean difference of the pain severity in the experimental group was $2 \mathrm{~cm}$ after the laser radiation at the second session that showed a statistically significant difference ( $p$ $=0.016)$, but this difference was not significant in the control group $(\mathrm{P}=0.630)$. There was no statistically significant difference at the third session in the pain mean severity in the experimental group before and after treatment which was mainly caused because of mothers' discharge of the hospital and the sample drop. The results of this study have suggested that the pain during the breastfeeding is greatly reduced using the low intensity laser therapy and it can be a good option for immediate relief of the nipple pain [28].

\subsection{Silver and silver cap}

For centuries, silver has been known as a natural agent with anti-bacterial and remedy properties. Its particles destroy the bacterial respiratory system in the form of interacting with the bacterial respiratory chain enzymes after sticking to the surface of the cell membrane of the bacteria. It does not only stick to the cell membrane surface, but also penetrates the cells and then disables its enzymes and will kill the bacteria by producing the hydrogen peroxide. The silver cap not only prevents the entrance of microorganisms to the wound site, but also protects the nipple against trauma and attrition as a cover. The indirect healing effect of the silver is attributed to create a humid environment at the wound surface and eventually the duplication and migration of the epithelial cells in the affected site [29].

Marrazzu et al (2015) has investigated the effect of the silver cap on the nipple pain heal and reduction. After the participants were randomly grouped in two, the intervention and control group, then were recommended a standard care (personal hygiene protection and nipple care) along with rubbing the breast milk after each breastfeeding around the fissure. Both groups were taught the correct breastfeeding methods. The severity score was used to examine the fissure which measures its severity based on the sum of the score of the three main fissure variables (1. Pain: Numerical rating scale (NRS) is an 11-degree tool that is a $10 \mathrm{~cm}$ line on which 0 and 10 are determined for the beginning and the end to indicate the severity of the patient's pain. $0=$ no pain, $10=$ the most severe pain. 2 . Bleeding: to measure the amount of bleeding the scoring is as follows: $0=$ non-bleeding during breastfeeding, $1-3=$ sometimes bleeding during breastfeeding, $4-6=$ at least one case of bleeding during the day, 7-10= bleeding in each breastfeeding time. 3 . The fissure size was measured using a millimeter ruler and its largest was $10 \mathrm{~mm}$. In this scale $0=$ no fissure, $1-10=$ small, $11-20=$ moderate, more than $21=$ sever and we have only studied the women who were included in the moderate or severe groups. Duration of the study was 15 days and the examination was done in the $0,2 \mathrm{nd}, 7$ th and 15th days. Based on the results the silver cap is more effective to reduce and heal the nipple pain than the standard care, so that in the 7th day in the experimental group $69 \%$ and in the control group $21 \%$ had no pain. The fissure healing in 7 th and 15th days was $69 \%$ and $31 \%, 50 \%$ and $36 \%$ in the intervention and control group, respectively [30].

\subsection{Polyethylene film}

The Polyethylene protector will help the wound to heal by creating a humid environment, protect wound from mechanical sores and prevent the bacterial invasion. Zimmer et al (1995) has studied the effect of the polyethylene film on the nipple fissure of 50 breastfeeding women. A polyethylene protector was randomly put for 7 days on a nipple (3-inch polyethylene film) and the other nipple was treated without as the control group. This polyethylene protector will remain on the nipple all the time, but only is taken away at the breastfeeding time. The examination was done through the photographic slides and oral descriptive scale in the 1st,3rd,5thand7thdays. Theoraldescriptivescaleisa6-degreetoolinwhich $0=$ nopainand6=severepain. Edema,blister,skincolorchange, desquamationandecchymosisareindependentlyexaminedaccordingtotheprovidedslidesandbytwoexperts.Thefissuremeanintheexperimentalgroupwas1.17whileitwas1.34inthecontrolgroup. Thisdifferencewasstatisticallysignificant $(\mathrm{p}<0.001), \quad$ there was also a significant statistical difference in the pain severity mean between these two groups $(\mathrm{p}<0.05)[31]$.

\subsection{Tea bag compress/hot water compress}

When the painful and injured site is heated, the area blood flow rate is in fact increased. Increasing the nitric oxide production by the vascular endothelial cells is the reason of increased blood flow rate through the heat. Increased blood flow rate in the injured site through the oxygen and nutrients will help to relive the pain and increase 
the wound healing rate [32].

The research units in the study of Lavergne (1995) were randomly placed in one of these three groups for five days: the tea bag compress on one breast and the hot water compress on the other, the hot water compress on one breast and non-treatment on the other, the tea bag compress on one breast and non-treatment on the other. The compress was done as follows: the research units put the tea bag and the breast pad in hot water then remove its extra water and put it on the breast for 15 minutes, the process repeats 4 times a day. The opposite breast, which had not received any treatment, was recommended to be exposed to the air for 15 minutes. Each sample was also a control group. The nipple soreness rating scale was used to determine the pain severity in which $0=$ no pain and no fissure, $5=$ the nipple fissure and severe pain during breastfeeding. The fissure status was also scored between 0 (no fissure) to 3 (visible fissure). The mother completely used these tools daily and after breastfeeding. The results showed that there was a significant statistical difference in the pain relief between the two groups of the hot water and the tea bag compress than to non-treatment group. The hot water and the tea bag compress were more effective than non-treatment. In the hot water and tea bag compress comparison, we have found that both were equally effective in the pain relief and there was no significant statistical difference in-between [33].

\subsection{Calendula officinalis (marigold)}

C. officinalis is an annual and herbaceous herb containing effective ingredients like flavonol glycosides,essentialfattyacids,saponinsandflavonoids[34]. Its flavonoids prevent the release of histamine and the production of prostaglandins as well as improving the inflammation and pain. Saponins will reduce the white blood cell movement to the flamed site by decreasing the capillary permeability and reducing histamine and then prevent plasma release into the tissue and also have the antibacterial and antifungal properties [35,36].

Kazemirad et al (2013) has divided the research units into 2 groups in his study. In the experimental group, calendite ointment (combination of hydro alcoholic extracts of the marigold and Echinacea angustifolia) was used 3 times a day after breastfeeding and the control group rubbed their breast milk around the nipple fissure. Both groups were taught the correct breastfeeding methods and subsequently were treated for a week. The nipple fissure score was measured before the study and in the 3rd and 7 th days after the study and recorded using Store Scale by the researcher. This scale has five degrees, 0 (the minimum score), 4 (the max-imum score). This scale will assess redness, edema and inflammation, the pain, the nipple fissure and bleeding. The results indicating that the fissure severity was homogeneous between both groups and its reduction in the 3rd day had no significant decrease $(\mathrm{p}=$ 0.2 ), but the ex-perimental group showed a significant difference at the 7th day $(p=0.006)$. According to these results, the calendit-E ointment was more effective than the breast milk [37].

\subsection{Ziziphus jujube (Jujube)}

Jujube with the scientific name of $Z$. jujube Miller is a fruit belongs to the Ramanacea family. It contains potassium, phosphorus, calcium, zinc, tannins, phenol flavonoids, phenolic acids, protein and fatty acids. Saponins and polysaccharides in the jujube have a major role in the safety activities and anti-inflammatory. Flavonoids, cyclopeptides, alkaloids and terpenes have anti-aesthetic, anti-microbial and anti-inflammatory properties. Gallic acid, catechins, caffeic acid, coumarines and chlorogenic acid are effective in reduction of inflammation [38,39].

Shahrahmani et al (2016) divided the women who had their first delivery and went to the women's clinic to do their baby's thyroid test on the third day after the birth and complained of their nipple fissure and pain into 2 groups as follows: they were selected based on a target-based method and input criteria-based and then were randomly grouped in the lotion of jujube or breast milk. The breastfeeding women in the control group rub 5 drops of their breast milk on their areola 5 times a day after breastfeeding and the experimental group do the same with $0.5 \mathrm{ml}$ of jujube lotion. A research assistant who was not aware of the treatment type measured and recorded the pain severity before the intervention 7th and 14th days after the treatment through a visual scale of the pain assessment. The pain severity score had no significant statistical difference before the intervention in both groups, but there was a significant statistical difference in both groups at 7 th and 14th days after the treatment $(\mathrm{p}=0.02$ and $\mathrm{p}=0.01)$. The results showed that the jujube lotion is more effective in the nipple pain relief than the breast milk [40].

\subsection{Aloe vera}

It is from the Soglas and asparagus genus. Because of the combinations such as glucoman-nan polysaccharide, carboxy peptidases, glucose, and all kinds of vitamins in it, the properties like antioxidant, antibacterial, antifungal, anti-inflammatory and healing are appeared [41]. The $A$. vera anti- inflammatory effect is attributed to the flavonoids, vitamins $A$ and $C$, sali-cylic acid (effective in inhibiting the formation of bradykinin and histamine) and arachidonic acid oxidation in it (effective in inhibiting prostaglandin synthesis) [42].

Tafazoli et al (2010) firstly selected the research units based on the target-based method and then divided them randomly into 2 groups: the experimental group $(A$. vera gel) and the con-trol (Lanolin) group. Both groups were taught the correct breastfeeding methods and the cor-rect use of the drug. The mothers were asked to rub the drug 3 times a day after breastfeeding for 7 days. The researchers were not aware of the treatment type. The researchers completed the Store Scale before the study and in the 3rd and 7th days during the study by visiting the women. The nipple fissure's mean score was as follows: in the $A$. veragel group before the study $=3.04$, in 3rd day $=1.26$ and in 7th day $=0.26$. In the lanolin ointment group before the study= 
3.1 , in 3rd day $=1.7$ and in 7 th day $=1.02$. Both groups were homogeneous in the nipple fissure mean score before the study $(\mathrm{P}>0.05)$. However, in the 3rd $(\mathrm{p}=0.048)$ and 7 th $(\mathrm{p}=0.003)$ days there was a significant difference between them. On the basis of the results the $A$. vera gel was more effective in the nipple fissure healing than the lanolin ointment alone [6].

\subsection{Mentha spicata}

Carvone, limonene, menthol and menthone are the ingredients in mint oil . Menthol has a specific receptor in the cell membrane and increases the threshold of cell stimulation through these receptors as well as blocks the flow and transition the pain signal by effecting on Kap-paopioid receptors and then leads to the pain relief and reduction $[43,44]$.

Four drops of menthol essence and breast milk were prescribed in Ali Akbari's et al study (2014) for the intervention and the control group, respectively. The nipple fissure and the pain severity were assessed using Amir Scale and VAS tool, respectively before and in the 10th and 14th days after the treatment. The nipple fissure severity mean in the experimental group was $8.31 \mathrm{~mm}$ before, $6.51 \mathrm{~mm}$ in the 10th day and $2.24 \mathrm{~mm}$ in the 14th day after treatment, respectively. It was $8.02 \mathrm{~mm}$ before, 7.39 in the 10th and $5.76 \mathrm{~mm}$ in the 14th day after the treatment in the control group. In the experimental group the pain severity mean was $148.55,4.26$ and $1.32 \mathrm{~mm}$ in days 3,10 and 14 , respectively, while it was $8.41,6.67$ and $4.32 \mathrm{~mm}$ in the control group, respectively. The results indicated that menthol essence relieved the pain and healed the nipple fissure [45].

Shanazi et al (2015) has examined the effect of mint, lanolin and dexpanthenol on the nipple fissure. Mothers in this study were randomly grouped in 3 . The lanolin tube contained pure lanolin without additives, the mint tube contained carbopol, methyl paraben, triethanolamine, glycerin and $2 \%$ mint and the dexpanthenol contained $5 \%$ B complex analogue. The tubes were similar in appearance. The researcher and the research units were not aware of the treat-ment type. People in 3 groups were treated 3 times per day for 2 weeks. The fissure status was examined before the intervention, in the 3rd, 7th and 14th days after the treatment. The re-sults suggested that lanolin, dexpanthenol and mint had a similar effect on the nipple fissure treatment [22].

Sayyah Melli et al (2007) had randomly divided the research units into 3 groups after babies' examination and mothers' breast physical examination. The lanolin, mint gel and placebo were similar in appearance and were marked with $\mathrm{A}, \mathrm{B}$ and $\mathrm{C}$. The participants were taught the cor-rect breastfeeding methods and the way of the drug usage. The assessment was done in the 4th, 7th, 10th, 14th and 42nd for the pain and fissure. The Amir Scale was used to determine the fissure status. The total fissure incidence was $11 \%$ in all three groups. (6.9\% in the lanolin group, $3.8 \%$ in the mint group and $22.6 \%$ in the placebo group), which was statistically signif-icant $(\mathrm{p}=0.01)$. The results showed that mint gel was more effective in the nipple fissure pre-vention than each one of lanolin and placebo [46].

\subsection{Guaiac/ Guaiazulene}

The crystalline hydrocarbon has derived from azulene that is taken from the gum of the Guaiacum tree. The Guaiac has these properties: anti-inflammatory, anti-infectious, anti-oxidant, anti-fungal, and epithelialization stimulant [47].

API et al (2005) measured the effect of the Guaiazulene ointment on prevention of the nipple fissure incidence. 153 mothers with no nipple fissure were randomly grouped into one of two groups: milked breast milk and Guaiazulene ointment $(0.05 \% \mathrm{w} / \mathrm{w})$. The experimental group was asked to rub the ointment after each breastfeeding at least 4 times a day for 1 month and the control group were advised to rub their breast milk on the nipple after each time of breastfeeding and expose it to the air for 1-2 minutes to be dried. The VAS tool measured the pain severity in the 15thand30thdaysaftertheintervention.Women'sfissurewasexaminedonthe30thdayafterthetreatment.Thetotalfissureincidencewas $31.4 \%, 18.4 \%$ ofwhichwasintheGuaiazulenegroupand $44.2 \%$ ofwhichwasinthebreastmilkgroup. Inthe15thdaytheGuaiazulenegroupnipplepain $(\mathrm{p}<0.05)$ wassignificantlylowerthanthebreastmilkgroupnipplepaininthe30thday $(\mathrm{p}<0.05)$. TheresultsindicatedthatusingGuaiazuleneointment $(0.05 \% \mathrm{w} / \mathrm{w})$ willeffectivelypreventthenipplefissureincidence[48].

\subsection{Portulaca oleracea}

The WHO has introduced $P$. oleracea as the most commonly used herbal medicine and it is attributed as the global Panacea. Its anti-inflammatory and anti-nociceptive effects are attributed to its available flavonoids, tannin, saponins and terpenoids [49-51]. The Omega 3 in $P$. oleracea is the most probable agent responsible for the anti-inflammatory effect by reducing inflammatory cytokines [52].

Niazi et al (2017) has randomly divided 86 breastfeeding women suffered from the nipple pain into two groups of 43 people after the explanation of the study goals and methods and obtaining a written consent letter: $P$. oleracea ointment and lanolin. Both groups were taught the correct breastfeeding method and drug usage. The researcher had measured and recorded the nipple pain score before the intervention and in the 3rdand8thdaysafterthetreatmentusingthepainnumericalratingscale. Theresultsshowedasignificantdifferenceinthepainseverityinthe3rdand8thdaysthanbeforeinbothgroupsandthepainseveritywasdecreasedinboth $(\mathrm{P}<0.001)$. Thepainseveritywaslowerinthe3rdand8thdaysinthe $P$. oleracea group than to the lanolin group $(\mathrm{P}<0.001)[53]$.

\section{Discussion}

We performed the current study to find and determine 
the nipple fissure and pain prevention and treatment methods. The assessed studies are acceptable and most of them scored more than 3 based on the Jadad scale. In Centuori et al (1999)'s opinion teaching the correct breastfeeding method is more effective than other interventions. The correct breastfeeding method teaching was the first action to prevent and treat the nipple fissure in the majority of the studies which can indicate the importance of the mother and the baby position during the breastfeeding $[21,54]$. There was no significant difference between the tea bag and hot water compress in Lavergne et al (1995) study. Although both compresses are good for the nipple fissure treatment, but the tea bag compress can have an effect on possible changes of the breast milk odor and taste [33]. The Hydrogel dressing will increase wound healing rate by creating a humid environment and it is an effective treatment to relieve the nipple pain in the breastfeeding women but will also increase the infection risk. The nipple fissure healing in the lanolin and the breast protector groups in Brent et al (1998) study was significantly more than the hydrogel group. When the combined treatment is used in one group, the effectiveness of each of the treatments is not clear and the results of Brent study due to using the lanolin or the breast protector are unclear [20]. Jackson's study (2016) results suggested that the lanolin is not effective in the nipple pain relief [10]. Dennis et al (2012) has shown in his study that there was no difference in the pain severity between the groups used the APNO and the one used the lanolin [23]. Tafazoli et al (2010) has indicated that the $A$. vera is more effective in the nipple fissure treatment than lanolin. In the other study lanolin had similar treatment effectiveness in the nipple fissure with menthol and dexpanthenol [6]. Based on the results of the available studies, it seems that much more studies with sufficient sample size must be done to verify or reject the effect of lanolin on the nipple fissure healing. The silver cap has some advantages: it is washable, it can be reused, and it has no effect on the breast milk odor and taste. The silver cap was more effective in Marrazzu et al (2015) study in the nipple fissure pain relief and treatment, but the small sample size of his study can have an effect on the results and can increase false positive results risk [30]. In the Coca (2016) study the low level laser had a significant effect on the nipple pain relief, but its high cost makes problems using this type of treatment for everyone [28]. Two studies were conducted on mint effects on the nipple fissure and pain which had acceptable design and validation. They had confirmed that the mint was effective. The results of 5 studies assessing the effects of the Calendit-E, A. vera, Jujube and Guaiazulene suggested that these herbs have positive effectiveness on the nipple fissure and pain prevention and relief, but due to the limited access of each of these studies further researches can be helpful. The pain severity and the fissure healing were examined by phone in some of these studies which could lead to bias in scoring. This systematic review has its own limitations, the most important of them is to lack of access to the all of the published articles and reports and the next problem is incorrect, low quality and inapplicable reports of some articles. The results of this study can be used to improve mothers' health and the quality of health services as well as selecting the appropriate thera- pies for the nipple fissure and pain treatment.

\section{Conclusion}

Some of the effective therapies for the nipple fissure and pain prevention and treatments are using: menthol, hot water compress and teaching the correct breastfeeding methods. The number of studies for other applicable drug and non-drug treatments are limited and the final conclusion needs studies with appropriate methodology and sample size.

\section{Acknowledgment}

Thanks to all of the researchers and authors whose studies were used in this article.

\section{Conflict of interest}

The authors declare that they have no conflicts of interest.

\section{References}

1. A.K. Leung, R.S. Sauve. Breast is best for babies, Journal of the National Medical Association. 2005;97(7):1010-9.

2. A. Mohammadzadeh, A. Farhat, H. Esmaeily. The effect of breast milk and lanolin on sore nipples. Saudi medical journal. 2005;26(8):1231-4.

3. M.M. Heller, H. Fullerton-Stone, J.E. Murase. Caring for new mothers: diagnosis, management and treatment of nipple dermatitis in breastfeeding mothers. International journal of dermatology. 2012;51(10):1149-61.

4. O.M. Agunbiade, O.V. Ogunleye. Constraints to exclusive breastfeeding practice among breastfeeding mothers in Southwest Nigeria: implications for scaling up. International breastfeeding journal. 2012;7:5.

5. O.M. Agunbiade, O.V. Ogunleye. Constraints to exclusive breastfeeding practice among breastfeeding mothers in Southwest Nigeria: implications for scaling up, International Breastfeeding Journal. 2012;7(1):5.

6. M. Tafazoli, R. Saeedi, M. Gholami Robatsangi, R. Mazloom. Aloevera gel Vs. lanolin ointment in the treatment of nipple sore: a randomized clinical trial. Tehran University Medical Journal. 2010;67(10).

7. F. Vieira, M.M. Bachion, D.D. Mota, D.B. Munari. A systematic review of the interventions for nipple trauma in breastfeeding mothers. Journal of nursing scholarship : an official publication of Sigma Theta Tau International Honor Society of Nursing. 2013;45(2):116-25.

8. A. Seyyedeh Hanieh, A. Sedigheh, B. Alireza Akbarzadeh, E. Somayeh. Effects of Aloe vera gel on breast fissures in breastfeeding women. Pajoohandeh. 2014;19(1):13-17.

9. J.C. Kent, E. Ashton, C.M. Hardwick, M.K. Rowan, E.S. Chia, K.A. Fairclough, et al. Nipple Pain in Breastfeeding Mothers: Incidence, Causes and Treatments. International Journal of Environmental Research and Public Health. 2015;12(10):12247-12263. 
10. K.T. Jackson, C.L. Dennis. Lanolin for the treatment of nipple pain in breastfeeding women: a randomized controlled trial. Matern Child Nutr. 2017;13(3).

11. V.B. Rahimi, V.R. Askari, S.A. Emami, Z. Tayarani-Najaran. Anti-melanogenic activity of Viola odorata different extracts on B16F10 murine melanoma cells. Iranian journal of basic medical sciences. 2017;20(3):242-249.

12. F. Forouzanfar, S. Torabi, V.R. Askari, E. Asadpour, H.R. Sadeghnia. Protective Effect of Diospyros kaki against Glucose-Oxygen-Serum Deprivation-Induced PC12 Cells Injury. Advances in pharmacological sciences. 2016;3073078.

13. V.R. Askari, N. Fereydouni, V. Baradaran Rahimi, N. Askari, A.H. Sahebkar, P. Rahmanian-Devin, et al. Beta-Amyrin, the cannabinoid receptors agonist, abrogates mice brain microglial cells inflammation induced by lipopolysaccharide/interferon-gammaand regulates Mphil/Mphi2 balances, Biomedicine \& pharmacotherapy $=$ Biomedecine \& pharmacotherapie. 2018;101:438-446.

14. V.R. Askari, V. Baradaran Rahimi, A. Ghorbani, H. Rakhshandeh. Hypnotic Effect of Ocimum basilicum on Pentobarbital-Induced Sleep in Mice. Iranian Red Crescent Medical Journal. 2016;18(7):e24261.

15. V.R. Askari, V. Baradaran Rahimi, S.A. Rezaee, M.H. Boskabady. Auraptene regulates Th1/Th2/TReg balances, NF-KB nuclear localization and nitric oxide production in normal and Th2 provoked situations in human isolated lymphocytes. Phytomedicine. 2018;43:1-10.

16. M. Renfrew, M.W. Woolridge, H.R. McGill. Enabling women to breastfeed: a review of practices which promote or inhibit breastfeeding-with evidence-based guidance for practice. Stationery Office London2000. 2000;

17. D. Moher, L. Shamseer, M. Clarke, D. Ghersi, A. Liberati, M. Petticrew, et al. Preferred reporting items for systematic review and meta-analysis protocols (PRISMA-P) 2015 statement. Systematic Reviews. 2015;4(1):1.

18. A.R. Jadad, R.A. Moore, D. Carroll, C. Jenkinson, D.J. Reynolds, D.J. Gavaghan, et al. Assessing the quality of reports of randomized clinical trials: is blinding necessary?. Controlled clinical trials. 1996;17(1):1-12.

19. H. Engel, S.W. Kao, J. Larson, S. Uriel, B. Jiang, E.M. Brey, et al. Investigation of Dermis-derived hydrogels for wound healing applications. Biomed J. 2015;38(1):5864.

20. N. Brent, S.J. Rudy, B. Redd, T.E. Rudy, L.A. Roth. Sore nipples in breast-feeding women: a clinical trial of wound dressings vs conventional care. Archives of pediatrics \& adolescent medicine. 1998;152(11):10771082.

21. S. Centuori, T. Burmaz, L. Ronfani, M. Fragiacomo, S. Quintero, C. Pavan, et al. Nipple care, sore nipples, and breastfeeding: a randomized trial, Journal of human lactation. Official journal of International Lactation Consultant Association. 1999;15(2):125-30.

22. M. Shanazi, A.F. Khalili, M. Kamalifard, M.A. Jafarabadi, K. Masoudin, F. Esmaeli. Comparison of the effects of lanolin, peppermint, and dexpanthenol creams on treatment of traumatic nipples in breastfeeding moth- ers. Journal of caring sciences. 2015;4(4):297.

23. C.L. Dennis, N. Schottle, E. Hodnett, K. McQueen. An all-purpose nipple ointment versus lanolin in treating painful damaged nipples in breastfeeding women: a randomized controlled trial, Breastfeeding medicine. The official journal of the Academy of Breastfeeding Medicine. 2012;7(6):473-9.

24. A.P. de Sousa, J.N. Santos, J.A. Dos Reis, Jr., T.A. Ramos, J. de Souza, M.C. Cangussu, et al. Effect of LED phototherapy of three distinct wavelengths on fibroblasts on wound healing: a histological study in a rodent model. Photomedicine and laser surgery. 2010;28(4):547-52.

25. M.E. Chaves, A.R. Araujo, S.F. Santos, M. Pinotti, L.S. Oliveira. LED phototherapy improves healing of nipple trauma: a pilot study. Photomedicine and laser surgery. 2012;30(3):172-8.

26. J.T. Hashmi, Y.-Y. Huang, S.K. Sharma, D.B. Kurup, L. De Taboada, J.D. Carroll, et al. Effect of Pulsing in Low-Level Light Therapy. Lasers in surgery and medicine. 2010;42(6):450-466.

27. M.L. de Moraes Maia, M.A. Ribeiro, L.G. Maia, J. Stuginski-Barbosa, Y.M. Costa, A.L. Porporatti, P.C. Conti, et al. Evaluation of low-level laser therapy effectiveness on the pain and masticatory performance of patients with myofascial pain. Lasers in medical science. 2014;29(1):29-35.

28. K.P. Coca, K.O. Marcacine, M.A. Gamba, L. Corrêa, A.C.C. Aranha, A.C.F. de Vilhena Abrão. Efficacy of low-level laser therapy in relieving nipple pain in breastfeeding women: a triple-blind, randomized, controlled trial. Pain Management Nursing. 2016;17(4):281-289.

29. S.L. Percival, S.M. McCarty. Silver and Alginates: Role in Wound Healing and Biofilm Control. Advances in wound care. 2015;4(7):407-414.

30. A. Marrazzu, M.G. Sanna, F. Dessole, G. Capobianco, M.D. Piga, S. Dessole. Evaluation of the effectiveness of a silver-impregnated medical cap for topical treatment of nipple fissure of breastfeeding mothers, Breastfeeding medicine. The official journal of the Academy of Breastfeeding Medicine. 2015;232-8.

31. M.M. Ziemer, D.M. Cooper, J.G. Pigeon. Evaluation of a dressing to reduce nipple pain and improve nipple skin condition in breast-feeding women. Nursing research. 1995;44(6):347-51.

32. J. Petrofsky, L. Berk, G. Bains, I.A. Khowailed, T. Hui, M. Granado, et al. Moist heat or dry heat for delayed onset muscle soreness. Journal of clinical medicine research. 2013;5(6):416-25.

33. N.A. Lavergne. Does application of tea bags to sore nipples while breastfeeding provide effective relief?. Journal of obstetric, gynecologic, and neonatal nursing : JOGNN. 1997;26(1):53-8.

34. A. Baghizadeh, S. Ranjbar, V.K. Gupta, M. Asif, S. Pourseyedi, M.J. Karimi, et al. Green synthesis of silver nanoparticles using seed extract of Calendula officinalis in liquid phase. Journal of molecular liquids. 2015;207:159-163.

35. P.K. Chandran, R. Kuttan. Effect of Calendula officinalis flower extract on acute phase proteins, antioxidant defense mechanism and granuloma formation during thermal burns. Journal of clinical biochemistry and nu- 
trition. 2008;43(2):58-64.

36. B. Muley, S. Khadabadi, N. Banarase. Phytochemical constituents and pharmacological activities of Calendula officinalis Linn (Asteraceae): a review. Tropical Journal of Pharmaceutical Research. 2009;8(5).

37. M. Kazemirad, N. Khodakarami, J. Salamzadeh, N. Nasiri, M. Kazemi, F. Moattar. Comparison of calendit-e cream versus expressed breast milk. Journal of Shahid Beheshti School of Nursing \& Midwifery. 2013;23(80):5380-5380.

38. S. Wang, J. Zhang, Z. Zhang, W. Gao, Y. Yan, X. Li, C. Liu. Identification of Chemical Constituents in the Extract and Rat Serum from Ziziphus Jujuba Mill by HPLCPDA-ESI-MSn. Iran J Pharm Res. 2014;13(3):1055-63.

39. R. Goyal, P.L. Sharma, M. Singh. Possible attenuation of nitric oxide expression in anti-inflammatory effect of Ziziphus jujuba in rat. J Nat Med. 2011;65(3-4):514-8.

40. N. Shahrahmani, S. Amir Ali Akbari, F. Mojab, M. Mirzai, H. Shahrahmani. The effect of Zizyphus Jujuba fruit lotion on improvement of nipple fissure pain in breastfeeding primipara women. The Iranian Journal of Obstetrics, Gynecology and Infertility. 2016;19(35):1321.

41. S.A. Hashemi, S.A. Madani, S. Abediankenari. The Review on Properties of Aloe Vera in Healing of Cutaneous Wounds. BioMed Research International 2015. $2015 ; 714216$.

42. F. Nejatzadeh-Barandozi. Cytogenetical Survey of Aloe vera populations in Iran. New Cellularand Molecular Biotechnology Journal. 2014;4(13):37-42.

43. C.E. Wright, W.P. Bowen, T.J. Grattan, A.H. Morice. Identification of the L-menthol binding site in guinea-pig lung membranes. British journal of pharmacology. 1998;123(3):481-486.

44. M. Okazawa, T. Terauchi, T. Shiraki, K. Matsumura, S. Kobayashi. l-Menthol-induced $[\mathrm{Ca} 2+]$ i increase and impulses in cultured sensory neurons. Neuroreport. 2000;11(10):2151-2155.

45. S.A.A. Akbari, S.H. Alamolhoda, A.A. Baghban, P. Mirabi. Effects of menthol essence and breast milk on the improvement of nipple fissures in breastfeeding women. Journal of Research in Medical Sciences : The Official Journal of Isfahan University of Medical Sciences. 2014;19(7):629-33.

46. M.S. Melli, M.R. Rashidi, A. Nokhoodchi, S. Tagavi, L. Farzadi, K. Sadaghat, et al. A randomized trial of peppermint gel, lanolin ointment, and placebo gel to prevent nipple crack in primiparous breastfeeding women. Medical science monitor : international medical journal of experimental and clinical research. 2007;13(9):Cr406-411.

47. T. Gunes, M.A. Akin, D. Sarici, K. Hallac, S. Kurtoglu, T. Hashimoto. Guaiazulene: a new treatment option for recalcitrant diaper dermatitis in NICU patients. The Journal of Maternal-Fetal \& Neonatal Medicine. 2013;26(2):197-200.

48. M. Api, D. Sivri, O. Api, H. Görgen, A. Çetin, M. Yayla. Prevention of nipple cracks with Guaiazulene versus breast milk in nursing mother: A randomized, controlled, doubleblind trial. J Turkish German Gynecol Assoc. 2005;6(4):279-84.
49. V.R. Askari, S.A. Rezaee, K. Abnous, M. Iranshahi, M.H. Boskabady. The influence of hydro-ethanolic extract of Portulaca oleracea L. on Th1/Th2 balance in isolated human lymphocytes. Journal of ethnopharmacology. 2016;194:1112-1121.

50. M.H. Boskabady, M. Hashemzehi, M.R. Khazdair, V.R. Askari. Hydro-ethanolic Extract of Portulaca oleracea Affects Beta-adrenoceptors of Guinea Pig Tracheal Smooth Muscle. Iranian Journal of Pharmaceutical Research : IJPR. 2016;15(4):867-874.

51. M. Hashemzehi, M. Khazdair, M. Kiyanmehr, V. Askari, M. Boskabady. Portulaca olerace Affects Muscarinic Receptors of Guinea Pig Tracheal Smooth Muscle. Indian Journal of Pharmaceutical Sciences. 2016;78(3):388394.

52. H.O. Obeng, B. Schwartz, W.A. Plahar. Can Leafy Vegetable Source of Omega-3 fatty Acids Ameliorate Acute Intestinal Inflammation Induced in Mice? A Case study of Purslane (Portulaca oleracea). European Journal of Medicinal Plants. 2015;6(2):70.

53. A. Niazi, S. Yousefzadeh, H. Rakhshandeh, H. Esmaily. Comparison of purslane cream and lanolin on the nipple pain breastfeeding women: a randomized clinical trial. The Iranian Journal of Obstetrics, Gynecology and Infertility. 2017;-.

54. V.B. Rahimi, V.R. Askari, S.A. Emami, Z. Tayarani-Najaran. Anti-melanogenic activity of Viola odorata different extracts on B16F10 murine melanoma cells. Iranian Journal of Basic Medical Sciences. 2017;20(3):242-249. 